\title{
Effectiveness of Policy Responses to Terms of Trade Shocks in Selected African Countries
}

\author{
Benedict I. Ezema \\ Department of Economics, Nnamdi Azikiwe University \\ P. M. B 5025, Awka, Anambra State, Nigeria \\ E-mail: benibeezema@gmail.com
}

Received: January 5, 2012

Accepted: February 7, $2012 \quad$ Published: April 16, 2012

doi:10.5539/ijbm.v7n8p88

URL: http://dx.doi.org/10.5539/ijbm.v7n8p88

\begin{abstract}
The terms of trade have an especially marked impact on the economies of developing countries. Some researchers suggest that terms of trade fluctuations are twice as large in developing countries as in developed countries. This movement in their terms of trade is a key determinant of macroeconomic performance and has an important impact on real national income resulting in terms of trade shocks. But African countries have not responded appropriately to these shocks hence this study was carried out to compare the impacts of the application of policy adjustments to terms of trade shocks among selected African countries, and to assess the extent to which these countries respond to the shocks. The study decomposed and estimated critical performance measures of the economic impacts of these adjustments to terms of trade shocks in these countries for the period 1970-2009 into quantifiable economic indicators namely: changes in import intensity, economic compression, export promotion and external debts. The application of the McCathy, Neary and Zanalda (1994) method confirms that adverse terms of trade shocks are not only high in Africa but that policy indicators refuse to adjust appropriately in the face of steep fall in export prices as clearly seen in the 1980 to 1984 period for Gabon and Nigeria. Secondly, the application of a Wilcoxon Matched-Pairs test reveals that the impact of policy responses to terms of trade shocks in oil exporting countries and agricultural commodity exporting countries of Africa are markedly different. The study, therefore, advocates that African countries should, henceforth, take practical steps to ameliorate the adverse effects of terms of trade shocks by carefully selecting and engaging policy thrusts that suit their particular economic problems and environments.
\end{abstract}

Keywords: Terms of trade shocks, Policy responses, Africa

\section{Introduction}

"All that Glitters May Not Be Gold" is the title of the Inter-American Development Bank 2007 Annual Report, partly in reference to the fiscal positions of Latin American countries during the latest boom in commodity prices. This report concludes that the fiscal surpluses observed during this boom period are far from reassuring since they are based on inflated and unsustainable fiscal revenues due to transitory increases in the price of commodities (Kaminsky, 2010). This concern is not limited to Latin America. Both in academic and policy circles the debate regarding what governments in commodity producer countries should do when their terms of trade improve or deteriorate has intensified. A characteristic common to the commodity-exporting developing countries of Africa is that movement in their terms of trade is a key determinant of macroeconomic performance and has an important impact on real national incomes (Cashin and Pattillo, 2000). Such terms of trade induced shocks to real incomes in developing countries often necessitate domestic policy responses which differ across countries.

The terms of trade have an especially marked impact on the economies of developing countries. Baxter and Kouparitsas (2000) suggest that terms of trade fluctuations are twice as large in developing countries as in developed countries. The authors attribute this pattern to the heavy reliance of developing countries on commodity exports, whose prices are more volatile than those of manufactured goods. Moreover, because developing countries generally have a high degree of openness to foreign trade, these sharp swings in the terms of trade affect a large share of their economies. Developing countries are also very exposed to terms of trade fluctuations because they have little, if any, leverage over their export prices (Broda, 2004). World markets dictate the price of the goods they export. By contrast, developed countries and oil exporters can exert a 
substantial influence on export prices. As documented by Madavo, Tomlinson, Mills, and Addison (2003), African countries have one of the world's most volatile terms of trade. They maintain that Nigeria for example, has been strongly penalized, at the rate of almost 1.6 percent per annum. By contrast, the fastest growing nations lose only 0.4 percent per annum due to terms of trade volatility.

The relationship between terms of trade shocks and economic development in Africa is an important issue because of its implications on the resources accruing from commodity exports. The impacts of such shocks have been extensively documented. For example, Mendoza (1995) and Kose (2002) find that terms of trade shocks account for at least half of the output volatility in developing countries, while Barro (1996) documents that sustained deteriorations in a country's terms of trade can have a significantly negative impact on growth. Agenor et al (2000) also documents that terms of trade disturbances are highly correlated with output fluctuations and can be a major source of aggregate economic volatility. Such disturbances tend also to have a large impact on savings (both private and public), in part because of their large income effects.

More importantly, responses to such terms of trade shocks have been low. While most African countries are subject to quite large external shocks, policy choices have added to the level of volatility of these countries (Madavo et. Al., 2003). These low responses have negative impact on national income, domestic price level, expenditure, investment, exchange rate, external debt, inflation, trade balance and other macroeconomic variables. Poor handling of the shocks therefore means a reduction in the economic wellbeing of the citizens because of its adverse implications on macroeconomic performance. Good policies enhance growth, and poor policies slow it down; very poor policies can set development back by decades. Of course, a country's resources and the international environment in which it trades will have a critical effect on its standard of living. But the extent to which these resources can raise a country's standard of living depends on economic policy. The belief is that good policies pay off, slowly and steadily, and bad policies do not pay and can be dramatically expensive.

In the policy debate on the causes of the steady deterioration in the Sub-Saharan Africa's export performance since the early 1970's, it has been argued that African governments have handled terms of trade shocks extremely badly and that inability to cope with external shocks has contributed to Africa's debt problems and very low rate of economic growth (Cashin and Pattillo, 2000). As a result of this mishandling, the gains obtained from positive terms of trade shocks have been small, while real losses from negative shocks have been large. For example, many African governments responded to commodity price booms in the late 1970s by sharply expanding public expenditure for hastily executed, import-intensive public investment programs that they either abandoned or financed with foreign borrowing when revenues subsequently fell because of steep declines in commodity prices. In Nigeria, the gains that should have been made possible by the relatively short-lived but nevertheless immense increase in oil earnings had not, apparently, been realized (Gavin, 1993).

Other African countries cannot also be said to have realized the full benefits of the huge earnings in their commodity exports. This raises some important questions on the validity of the policy applications to these shocks in Africa which this study seeks to address. How effective are policy responses to terms of trade shocks in Africa? Are the impacts of policy responses to terms of trade shocks in oil exporting countries and agricultural commodity exporting countries of Africa the same? To effectively proffer answers to these questions, this study will attempt quantitative estimation of the impact of the responses to terms of trade shocks on the macroeconomic variables highlighted earlier in the selected African countries.

\section{Policy Responses}

Terms of trade is one of the most important relative prices in economics. The ratio of the prices of a country's exports to the prices of its imports defines the net barter terms of trade, which measures the number of units of imports that can be exchanged for a unit of exports. The key determinant of the long-term impact on income of terms of trade changes is the elasticity of substitution in production between labor and the imported intermediate goods in both the non-traded and traded goods sectors (Iscan, Powel and Rebucci, 2009). These researchers stress that the elasticity contributes to determining the magnitude of relative price changes and hence the income and substitution effects which in turn determine the responses of aggregate consumption and production to the shocks, and associated reallocation of labor across sectors. In principle, there is very little that economic policy can do to influence the elasticity of substitution in production but they insist that economic policy can interact with this elasticity and indirectly influence the vulnerability of an open economy to fluctuations in the terms of trade. They further maintain that the reallocation of labor across sectors in response to terms of trade shocks, in particular, may be affected by the degree of labor mobility, both national and international, as well as by immigration and tax policies (including on international trade). Thus, labor market rigidities, poor social safety nets, and migration policies are important. Terms of trade shocks modify the international relative prices of 
exported and imported goods. Small open economies have little or no influence over these international price changes. As a result of terms of trade shocks, domestic prices of exported and imported goods also tend to change, including on the relative price of non-traded goods. That is, relative price changes in international markets pass-through to domestic prices.

Moreover, the source of revenue volatility in most African countries is their dependence on primary commodity exports. These commodities have unstable prices in the world market and always superimpose revenue volatility after boom and burst cycles. For instance, most of Nigeria's revenue volatility can be traced directly to Nigeria's dependence upon oil exports for the bulk of its fiscal revenues. Table 1 shows oil receipts and the fiscal situation in Nigeria, 1970-83 (percentage of GDP). In most cases, spending becomes more than proportional to revenue windfalls when the political and legal institutions within a nation are weak and contested by strong interest groups (Ezema, 2009).

There are at least three other important additional channels of transmission of terms of trade shocks as documented by Iscan, Powel and Rebucci (2009). First, there are effects through asset price changes, which are affected by the degree of international financial market incompleteness and capital mobility. Second, there are important effects through physical capital mobility across sectors. Third there is monetary and exchange rate policy. Responses to terms of trade shocks are packaged in the fiscal, monetary, exchange rate and other regulatory policies of government.

\section{Brief Review of Literature (Theoretical and Empirical)}

Various schools of thought have emerged with divergent views on the right policy responses in resolving the problems associated with terms of trade shocks. Dixit (1989) leads the school of thought that believes in the prompt resolution of the "uncertainty problem" as a panacea for addressing the issue of distortions associated with terms of trade shocks. In the real world, nobody knows for certain whether a change in the terms of trade will be persistent or temporary. But Cashin and Pattillo (2000) argue that nobody can assess a country's economic policy without an awareness of the uncertainty that surrounds future movements in her terms of trade. This leads the researchers to suggest a conservative approach to adjusting to a change in the terms of trade. Conservative in this context means two things. First, it means a higher rate of saving than would be appropriate under certainty. Second, it means avoiding irreversible commitments-or commitments that are costly to reverse-when there is substantial uncertainty about future developments.

Some other economists stress expenditure-based responses which are based on a simple rule for consumption known as permanent income hypothesis (Gavin, 1993). This school argues that if the change in the terms of trade is persistent, it leads to a permanently lower level of income. In this case, the best response is for consumption to decline immediately to the new, lower level of national income; only such a policy maintains a smooth path for consumption while still respecting the lifetime budget constraint. If however, the change in the terms of trade is expected to be transitory, then it does make sense to borrow from abroad to cushion the short-run effects on domestic expenditure. But the production-based responses on the other hand suggest that when it takes time to adjust the production sector, even persistent changes in the terms of trade should, in part, be financed by foreign borrowing (Gavin, 1993). This school insists that in the real world, moving from one production equilibrium to another takes time and is costly and bearing these costs of adjustment will not be worthwhile if the deterioration in the terms of trade is expected to last for only a very short time.

There are yet others who advocate adjustments based on relative prices which emphasize the fact that changes in the terms of trade have both income and price effects. The price effect stresses that an improvement in the terms of trade makes imported consumption goods less expensive in relation to non-traded goods at any given relative price of exports and non-tradables (Dornbusch, 1983). This leads to conflicts with the substitution effect; which effect will dominate depends on the degree of substitutability between imported goods and the non-traded consumption goods. The most plausible supposition is that imported and non-traded goods are relatively poor substitutes in most developing economies, so that the case in which the income effects dominate is more prevalent. But other economists believe that true solution to the problems of terms of trade shocks lies in the investment decisions of the economic managers. This school believes that even when there is an improvement in the terms of trade, two investment questions still need to be resolved for the full benefits to be realized (Brock 1988). First, of the savings generated by an improvement in the terms of trade, how much should be invested abroad and how much should be invested in the domestic capital stock? Second, in what sectors should the investment take place?

The answer to the first question depends on the time horizon because the more frenetic the rate of investment, the more likely that bottlenecks will result in delay and waste and costly mistakes will be made. It is, therefore, 
recommended that a large share of the savings generated by an improvement in the terms of trade should be diverted into the accumulation of foreign assets which can be used to finance capital accumulation at a more moderate, and presumably less wasteful, pace. For the second question, the school recommends that a substantial share of the real appreciation generated by an improvement in the terms of trade should be invested in the nontradable sector. This will help to meet the increased demand for non-traded goods while the increased export earning takes care of the increased demand for foreign goods. Yet some others have insisted that addressing the Dutch disease problem is the crucial starting point to the positive adjustment of terms of trade shocks (Zafar 2004).

Empirically, high terms of trade variability are hard facts of life in most open economies. In 1998, the terms of trade of Nigeria declined by 28 percent but bounced back by a spectacular 38 percent from January 2000 through June 2000 (IMF 2000). These are large fluctuations by any reasonable standard, and they are representative of the exposure of small open economies to large and unpredictable swings in their terms of trade.

Using a sample of 66 developing countries, Bidarkota and Crucini (2000) find that among the top quartile of countries exhibiting the highest terms of trade volatility, the standard deviation of the country terms of trade was an extraordinary 25 percent per year. For the next three quartiles the standard deviations were 16, 12.5 and 8.5 percent respectively. This volatility poses a substantial challenge to government policy in light of the enormous difficulty in predicting shot-and medium-term trends in the terms of trade, as well as the documented ambiguity surrounding the persistency of terms of trade shocks (Cashin et al. 2000). The terms of trade of Ghana varied on an annual basis, from 1998 to 2000 by $9,-8.7$ and -20.3 percent, respectively. It is tempting to classify this volatility as malice of underdevelopment, but even industrialized economies are not immune from large and unpredictable shifts in their terms of trade. The terms of trade of Norway, for example, varied, on an annual basis, from January 1998 through June 2000 by $-8,-3$ and 11 percent, respectively (IMF, 2000). The risks induced by terms of trade shocks are therefore of considerable concern for a wide range of economies. There is no country in the world that has not experienced terms of trade shocks at one time or the other. It is policy thrusts among the countries that make most of the difference.

Cashin and Pattillo (2000) provided the measurement of the duration, variability and size of terms of trade shocks in most sub-Saharan African countries. The study shows that most oil producing countries in sub-Saharan Africa including Nigeria have large terms of trade shocks (Cashin and Pattilo, 2000). CIA World Factbook (2006) and Oxford Business School (2007) insist that institutional settings are crucial factors in tackling the problem. Nigeria ranks among the most volatile economies in the world and terms of trade shocks are the major reasons for this unstable nature of the economy (Madavo, Tomlinson, Mills and Addison, 2003). The terms of trade index defined as the index of export prices divided by an index of import prices shows that Nigeria is first out of 110 countries for the standard deviation of terms of trade in levels, 1960 - 2000. If one looks at volatility of the growth rate of the terms of trade index, then Nigeria is ranked 3rd out of a sample of 90 countries for the period 1961-2000. The standard deviation in Nigeria's terms of trade growth rates over that period was 27 percent compared to the sample median of only 10 percent.

In general, those countries with high terms of trade volatility tend to also display high real exchange rate volatility. The real exchange rate is defined as the exchange rate in US \$ per Naira, adjusted by the ratio of Nigerian to trading partner inflation. With a sample of 87 countries, 31 displayed high terms of trade volatility over the period 1980-94. Of these, 25 had high real exchange rate volatility. The outcome depends upon whether fiscal expenditures are pro-cyclical or counter-cyclical with regard to revenues.

A cross-country analysis shows that real exchange rate uncertainty affects the profitability of investments through price channel and through the cost of borrowing. Bleaney and Greenaway (2001) and Serven (2002) use cross-country panel data and find that investment is reduced by real exchange rate instability. Risk-averse investors, in agriculture, manufacturing or services will hesitate to invest until they can be assured of strong profits. Second, volatility affects the ranking of investments: if the exchange rate is likely to depreciate, then a low ranked project in cocoa exports might become more profitable than a high ranked manufacturing enterprise that relies heavily on imported materials. Risk-averse investors thus tend to defer their decisions until more information is available, the uncertainty is reduced or they gain access to some form of insurance (risk diversification). Access to financial markets, both domestic and international, is crucial for the latter. Hence, as documented by Serven (2002), the adverse impact of real exchange rate uncertainty is stronger for economies with less developed financial systems.

Despite the common dependence of sub-Saharan economies on commodity exports, the typical duration of terms of trade shocks varies from country to country. What accounts for this? The results of an empirical analysis 
(Cashin and Pattillo, 2000) reveal that terms of trade shocks tend to last longer (with everything else held constant) for countries:

- with large shares of petroleum imports in total imports (because petroleum price shocks tend to be long lived);

- with small shares of non-fuel commodity exports in total exports (because many non-fuel exports are agricultural commodities, which tend to be subject to short-lived, weather-related supply shocks);

- countries whose exports are highly concentrated in commodities subject to long-lived price shocks.

For instance, oil-exporting counties will typically experience long lived shocks to their terms of trade, because oil is subject to long-lived price shocks.

In most oil states in Africa, the government is even more dependent on oil revenue than the overall economy (Ezema, 2009). This can create fiscal problems since government spending typically is not as volatile as oil revenue. The army, police, judiciary and health service all need to be paid when oil prices are low. Government employees are typically paid fixed salaries, not a salary linked to the price of oil. Government investment in roads, ports and other infrastructure can be reduced when government revenues fall, but such pro-cyclical adjustment in capital spending tends to augment the downturn associated with an oil price shock. In more technical terms, there is a mismatch between an 'oil' state's highly volatile revenue stream from oil, and its need to cover the stable fixed costs associated with operating a government.

Daniel (2001) maintains that there are lots of ways of trying to manage this mismatch. The government can build up fiscal reserves in good times, though in practice this can be hard because it requires resisting democratic pressure to spend fiscal reserves prematurely. The government can borrow to sustain spending in bad times. The government could engage in various hedging strategies - long term sales contracts, forward sales - that would limit the volatility in its oil revenues. The government could, in theory, index government salaries to the price of oil. Letting the exchange rate float also helps the government manage this mismatch. While there exist a wide variety of responses to economic shocks and several positive ways to manage volatility, many developing countries, particularly in Africa, have handled commodity-related shocks poorly-by printing money and fuelling inflation; over borrowing from commercial banks and multilateral institutions, and leading to spiraling debt; or failing to diversify the export base (IMF, 2003).

Agenor et al (2000) found evidences suggesting that terms of trade shocks can entail an asymmetric response in savings, as a result, for instance, of the existence of borrowing constraints on world financial markets. Citing the experience of the past few years, they suggest that households (and governments) from poor countries may be able to deposit their windfall savings on the international capital market in good times, but that they may be unable to borrow as much as they would like in bad times because of collateral problems or a (perceived) high risk of default (World Bank, 1999).

Using a group of 29 non-oil exporters of sub-Saharan African countries over the period 1980-1996, Agenor (2003) tried to re-enforce the evidences suggesting that terms of trade shocks have an asymmetric effect on private savings. It was found that primary commodities account on average for about three-fourths of total exports in most of them, and the share of commodities in some countries' exports exceeds $90 \%$ (World Bank, 2000). It was also found that access to world capital markets by many of these countries (which, to begin with, are relatively closed financially) tends to be asymmetric; it is often in "good times" (periods characterized in particular by high commodity prices and improvements in the terms of trade) that private capital tends to flow to low-income countries.

Agenor (2005) extended the study of the asymmetric effects of terms of trade shocks on savings (both public and private) to oil-exporting countries. Using the 1998 slump in commodity prices as a reference, he stressed that although the real income effect on primary commodity exporters was moderate (of the order of _ $0.5 \%$ of GDP), and net importers of oil and primary commodities actually registered a gain overall, oil exporters registered a negative real income effect of the order of _6.3\% of GDP (World Bank, 2000). Because oil exports account for almost all of government revenues in oil-exporting countries, the public sector bore the brunt of adjustment. The ability of each country to smooth public consumption in response to the revenue shortfall was, however, limited by their ability to draw down their official reserves and to borrow, both domestically and abroad. In many cases, constraints on domestic finance and lack of access to international capital markets actually prevented governments from successfully smoothing the impact of the oil price cycle, and economic performance deteriorated.

The same study by the World Bank (2000) also noted that although adjustment to the oil price swings in the past 
few years differed significantly across oil exporters, most countries increased their aggregate saving rates during the rise in oil prices in 1996-1997 (compared with 1993-1995) and reduced them during the 1998 slump. In addition, the savings response was found to be asymmetric: on average, saving rates rose by less than half of the real income gain during the 1996-1997 boom but fell by the full amount of the decline in real incomes during the 1998 collapse in prices. As emphasized by Deaton (1992), among others, this asymmetry can create an incentive for precautionary saving, because in the case of a negative shock consumption can be smoothed only by running down previously accumulated assets.

Broda and Tille (2003) observe the output effects of a 10 percent decline in export prices in seventy-five developing countries with differing exchange rate regimes. They find that two years after the price decline, real GDP is almost unaffected in countries with a flexible exchange rate, while it drops by about 2 percent in countries with a fixed exchange rate. These results provide strong support for the theory that a flexible exchange rate can help to insulate an economy against fluctuations in export and import prices. In a separate demonstration of the importance of the exchange rate regime, they narrowed their focus to two countries with fixed rate regimes, Ecuador and Argentina, to show how forcefully changes in the terms of trade will drive economic activity when the buffer of a flexible exchange rate is absent. Ecuador benefited from higher export prices after adopting the dollar as its currency in 2000, while Argentina faced sharp falls in export prices during 1998 and 1999. The calculations of Broda and Tille (2003) indicate that the contrary movements in the terms of trade experienced by these countries contributed heavily to divergent output performances. They also went ahead to provide an extensive survey to show that terms of trade, debt, growth, and risk are strongly linked in developing countries. Terms of trade shocks have also been closely linked to changes in capital flows by Caballero and Panageas (2003), and Calvo, Izquierdo, and Mejia (2004), who find that negative terms of trade shocks increase the likelihood of a sudden stop in capital inflows and large interest rate upswings. This evidence is consistent with the findings of Broda (2004) who observe that most crises are preceded by negative terms of trade shocks that caused substantial economic fluctuations and disruption to output growth.

Based on both the theoretical and empirical literature provide above, there is the need to measure and compare the effects of policy responses to terms of trade shocks in the selected African countries on macroeconomic performance by selecting quantifiable indicators of the economic impacts of these adjustments. Changes in import intensity, economic compression, export promotion and external debts provide good measures of such impacts. This study will attempt not only to quantify and measure these indicators but also to compare them in oil exporting countries with those of the primary commodity exporting countries of Africa.

\section{Methodology}

Two different models are adopted in this study to test economic relationships. The first tries to quantify and measure the four indicators; changes in import intensity, economic compression, export promotion and external debts for the various countries during the period 1970 to 2009. The second on the other hand attempts to make a quantitative comparison of the impacts of these responses on agricultural commodity exporting countries of Africa as against oil exporting countries. But before these models are highlighted, the first step is to start with the stationarity tests which were conducted using Dickey-Fuller and augmented Dickey-Fuller tests to detect stochastic trend. Dickey-Fuller is a test for a unit root in a time series sample or a test to determine whether a time series is stationary or, specifically, whether the null hypothesis of a unit root can be rejected.

The Dickey-Fuller test results confirmed stationarity hence stationarity tests were accepted because both the necessary and sufficient conditions for their significance were duly satisfied at between $1 \%$ and $5 \%$ critical levels. It was also found that more than two of the explanatory variables fell in the same order with the dependent variables (see table 2). Apart from the above tests, co-integration analysis/test was employed to bring the short-run dynamic specification relationship to their long-run specification. Over-parametization test was conducted at the first differencing since all the variables are stationary at the first order before the actual analyses.

\subsection{Model one}

The first model adopted a method developed in the early 1990s by World Bank researchers (McCarthy, Neary, and Zanalda) to measure the balance of payments response to external shocks in small open economies. The method draws from important literatures on the theory of distortions, and welfare. The researchers tried to understand country reactions in a policy making context by assessing the extent to which countries respond to terms of trade shocks. This method is anchored on the view that current shocks cannot be identified as either persistent or temporary (McCarthy, Neary, and Zanalda, 1994).It is very effective in analyzing Dutch disease societies. Quantitative methodology is applied to decompose policy responses to terms of trade shocks into four 
performance indicators: import intensity, economic compression, export promotion and external debt changes (a residual item). In very useful papers, Chami (1999) and Zafar (2004) extended the methodology to Oman and Gabon respectively, two prominent oil-exporting countries, and reached a variety of interesting conclusions on the role of countercyclical fiscal policy in shielding those economies from adverse shocks.

The first task of the model is to measure the terms of trade shocks for the various countries (McCarthy, Neary, and Zanalda, 1994). The variables used are given in the following equations:

$$
\begin{array}{cc}
\text { TOTT }_{t}=\text { TOTM }_{t}-\text { TOTX }_{t}=(1970-2009) & \text { a } \\
\text { TOTM }_{t}=\mathrm{VM}_{t}\left(\mathrm{PM}_{\mathrm{t}}-\mathrm{PM}_{\mathrm{t}-1}\right)=\text { import effect } & \mathrm{b} \\
\text { TOTX }_{\mathrm{t}}=\mathrm{Ve}_{\mathrm{t}}\left(\mathrm{PE}_{\mathrm{t}}-\mathrm{PE}_{\mathrm{t}-1}\right)=\text { export effect } & \mathrm{c}
\end{array}
$$

Adding together the import and export effects:

$$
\mathrm{TOTT}=\left(\mathrm{VM}_{\mathrm{t}}\left(\mathrm{PM}_{\mathrm{t}}-\mathrm{PM}_{\mathrm{t}-1}\right)\right)-\left(\mathrm{VE}_{\mathrm{t}}\left(\mathrm{PE}_{\mathrm{t}}-\mathrm{PE}_{\mathrm{t}-1}\right)\right.
$$

Where $\mathrm{VM}_{\mathrm{t}}=$ volume of merchandise imports

$\mathrm{PM}_{\mathrm{t}}=$ unit value of imports at time $\mathrm{t}$

$\mathrm{VE}_{\mathrm{t}}=$ volume of merchandise exports

$\mathrm{PE}_{\mathrm{t}}=$ unit value of exports at time $\mathrm{t}$

Equation $d$ represents the terms of trade shocks. A positive value for TOTT represents an adverse shock while a negative value represents a favorable shock. As documented by the World Bank, the fastest growing countries of the world lose only 0.4 percent of their GDP per annum due to terms of trade shocks (Madavo et al, 2003). Therefore, the benchmark used for measuring high terms of trade shocks in this study is any estimated absolute value that is greater than 0.4 percent per annum.

The first indicator is import intensity (MSUB) which measures the change in imports due to changes in import elasticity, assuming no changes in the growth rate. The variables are presented in the following equations:

$$
\begin{array}{cc}
\operatorname{MSUB}_{\mathrm{t}}=\mathrm{MH}_{\mathrm{t}}-\mathrm{MA}_{\mathrm{t} t}=(1970-2009) & \mathrm{e} \\
\mathrm{MH}_{\mathrm{t}}=\mathrm{M}_{\mathrm{t}-1}\left(1+\mathrm{EL}_{\mathrm{t}}\left(\mathrm{GDPGR}_{\mathrm{t}}\right)\right)=\text { hypothetical value of imports at time } \mathrm{t} \text { if } \mathrm{EL} \text { is constant } & \mathrm{f} \\
\mathrm{MA}_{\mathrm{t}}=\mathrm{M}_{\mathrm{t}-1}\left(1+\mathrm{GRVM}_{\mathrm{t}}\right)=\text { value of imports at time } \mathrm{t} \text { if price doesn't change } & \mathrm{h}
\end{array}
$$

Adding together $\mathrm{f}$ and $\mathrm{g}$ :

$$
\text { MSUB }_{\mathrm{t}}=\mathrm{M}_{\mathrm{t}-1}\left(\mathrm{EL}\left(\mathrm{GDPGR}_{\mathrm{t}}-\mathrm{GRVM}_{\mathrm{t}}\right)\right)
$$

where $\log \mathrm{V}=\mathrm{a}+\mathrm{b} \log$ GDP $\mathrm{b}=\mathrm{El}=$ the import elasticity to GDP expected at time $\mathrm{t}$

$\mathrm{V}_{\mathrm{t}}=$ Countrys import volume index at time $\mathrm{t}$

$\mathrm{GDPGR}_{\mathrm{t}}=\left(\mathrm{GDP}_{\mathrm{t}}-\mathrm{GDP}_{\mathrm{t}-1}\right) / \mathrm{GDP}_{\mathrm{t}-1}=$ growth rate of countrys GDP

$\mathrm{GRVM}_{\mathrm{t}}=\left(\mathrm{VM}_{\mathrm{t}}-\mathrm{VM}_{\mathrm{t}-1}\right) / \mathrm{VM}_{\mathrm{t}-1}$

Technological change is particularly captured by changes in the elasticity over time. If import intensification takes place, it means that a country's imports are higher than expected, and therefore, $\mathrm{MSUB}_{\mathrm{t}}$ will be negative.

The next indicator is economic compression (ECOM) which measures the effect on imports due to a slowdown in the economic growth rate, that is, the change in imports at time $t$ due to the compression of the economy. It is computed on the assumption that the elasticity of imports with respect to GDP does not change. The variables used are highlighted in the following equations:

$$
\begin{gathered}
\mathrm{ECOM}_{\mathrm{t}}=\mathrm{MVT}_{\mathrm{t}}-\mathrm{MH}_{\mathrm{t} \mathrm{t}}=(1970 \text { to 2009) } \\
\mathrm{MVT}_{\mathrm{t}}=\mathrm{M}_{\mathrm{t}-1}\left(1+\mathrm{EL}_{\mathrm{t}}\left(\mathrm{GDPT}_{\mathrm{t}}\right)\right)
\end{gathered}
$$

$\mathrm{MH}_{\mathrm{t}}=\mathrm{M}_{\mathrm{t}-1}\left(1+\mathrm{EL}_{\mathrm{t}}\left(\mathrm{GDPGR}_{\mathrm{t}}\right)\right)=$ hypothetical value of imports at time $\mathrm{t}$ if $\mathrm{EL}$ is constant

Substituting $\mathrm{k}$ and $\mathrm{l}$ in $\mathrm{j}$ :

$$
\mathrm{ECOM}_{\mathrm{t}}=\mathrm{M}_{\mathrm{t}-1}\left(\mathrm{EL}_{\mathrm{t}}\left(\mathrm{GDPT}_{\mathrm{t}}-\mathrm{GDPGR}_{\mathrm{t}}\right)\right)
$$

Where $\log G D P=a+b_{t} b=G D P T_{t}=$ expected trend growth rate in GDP at time $t$, based on the 10 years.

$$
\log \mathrm{V}=\mathrm{a}+\mathrm{b} \log \text { GDP } \mathrm{b}=\mathrm{EL}
$$

When economic compression takes place, $\mathrm{ECOM}_{t}$ assume positive values. Note that $\mathrm{ECOM}_{\mathrm{t}}$ is a measure of the effect of change in the growth rate alone (i.e. does not include the effect of change in elasticity). 
Finally, the last indicator which is export promotion (EPR) is estimated by comparing the growth in a country's exports by volume with world export growth. In order to have quantitative evidence on the development of the non-oil sector, Nigeria's non-oil export growth is to be compared with world export growth, with the difference suggesting the extent of diversification. In this way, it provides a good assessment of export promotion by comparing the country's export promotion to world exports. The variables are presented in the following equations:

$$
\mathrm{EPR}_{\mathrm{t}}=\mathrm{EA}_{\mathrm{t}}-\mathrm{EH}_{\mathrm{t}}=(1970 \text { to 2009) }
$$

$\mathrm{EA}_{\mathrm{t}}=\mathrm{E}_{\mathrm{t}-1}\left(1+\mathrm{GRVE}_{\mathrm{t}}\right)=$ the value of exports at time $\mathrm{t}$, at the price prevailing at time $\mathrm{t}-1 \quad \mathrm{p}$

$\mathrm{EH}_{\mathrm{t}}=\mathrm{E}_{\mathrm{t}-1}\left(1+\mathrm{GRXVW}_{\mathrm{t}}\right)=$ the value of exports at determined by changes in the volume of world exports

Substituting $\mathrm{p}$ and $\mathrm{r}$ in $\mathrm{n}$ :

$$
\mathrm{EPRGR}_{\mathrm{t}}=\mathrm{E}_{\mathrm{t}-1}\left(\mathrm{GRVE}_{\mathrm{t}}-\mathrm{GRXVW}_{\mathrm{t}}\right)
$$

Where $\mathrm{GRVE}_{\mathrm{t}}=\left(\mathrm{VE}_{\mathrm{t}}-\mathrm{VE}_{\mathrm{t}-1}\right) / \mathrm{VE}_{\mathrm{t}-1}=$ growth rate of Nigeria's export volume from time t-I to $\mathrm{t}$

$\mathrm{VE}_{\mathrm{t}}=\mathrm{E}_{\mathrm{t}} / \mathrm{PE}_{\mathrm{t}}=$ volume of merchandise exports

$\mathrm{GRXVW}_{\mathrm{t}}=\left(\mathrm{XVW}_{\mathrm{t}}-\mathrm{XVW}_{\mathrm{t}-1}\right) / \mathrm{XVW}_{\mathrm{t}-1}=$ growth rate of world export volume from time $\mathrm{t}-\mathrm{I}$ to $\mathrm{t}$

$\mathrm{XVW}_{\mathrm{t}}=$ Volume of world exports at time $\mathrm{t}$

A positive $E P R_{t}$ indicates that the country increased its share of world exports. This result might be interpreted as the consequence of an export promotion policy. However, EPRt is strongly dependent on changes in international conditions which are independent of domestic policies. Note also that the fourth indicator which is external debt changes or borrowing is a residual item.

\subsection{Model Two}

This model intends to quantitatively make a comparison of the results calculated in model one among the countries. It specifically seeks to find out if the impact of policy responses to terms of trade shocks in oil exporting countries and agricultural commodity exporting countries of Africa are markedly different. This test is conducted using a Wilcoxon Matched-Pairs Test (Signed Rank Test) which is a very important technique used to determine both direction and magnitude especially when the issue involves comparison as in 'before' and 'after', just like the current study which is dealing on terms of trade shocks during economic booms and bursts. The technique is good in testing means (averages). There is a marked difference if the calculated Wilcoxon absolute value is not significant (i.e. if the calculated Wilcoxon value is lower than the critical value) and vice versa.

The data required for the estimation of the two models relate to GDP growth in percentage, real exchange rate index, LIBOR rate, major export prices (e.g oil prices in $\$ /$ barrel for Nigeria and cocoa prices in $\$ /$ tonne for Cote $\mathrm{d}$ Ivoire), merchandise exports in billion $\$$ and merchandise imports in billion $\$$. These data are sourced from the IMF, World Bank and Central Bank of Nigeria.

\subsection{Selection of the Countries}

The major difficulty encountered during the study was the non-availability of relevant data for some African countries forcing the researcher to limit the number of countries to twelve. Nevertheless, the choice of the twelve African countries selected for the study is analytically interesting for several reasons. Firstly, care has been taken to ensure that all the regions of the entire African continent are represented. In the West, Nigeria, Ghana and Cote d'Ivoire were selected. East Africa is represented by Kenya, Malawi and Ethiopia while Central Africa has Gabon and Equatorial Guinea. In the South, the researcher chose Botswana and Zambia while Egypt and Sudan represent the North.

Secondly, each of the countries had suffered severe terms of trade shocks in the past which policymakers found increasingly difficult to tackle. In fact, Cashin and Pattillo (2000), were able to show that Nigeria along with few other African countries such as Kenya, Gabon and Cote d'Ivoire have the longest duration of terms of trade shocks. For some of the other countries, the duration of the shocks is not as long as that of Nigeria but the largeness of their shocks ranks high.

Thirdly, the mainstay of each economy is concentrated on the earning of a particular export commodity. These countries can be grouped based on their major export commodities namely:

- $\quad$ Oil exporting countries comprising Nigeria, Gabon, Sudan, Egypt, and Equatorial Guinea.

- Non-oil mineral resources exporting countries comprising Botswana and Zambia, which export diamond and copper respectively. 
- $\quad$ Agricultural commodity exporting countries as shown in table 3.

This grouping is important since some researchers argue that the same policy responses may create different impacts between an oil exporting country and an agricultural commodity exporting country.

It is important to conclude this section by emphasizing the fact that the share of the major export commodities to total exports for various countries differs. For instance, oil contributes roughly 90 percent of Nigeria's total exports while its contribution for Gabon is between 70 to 80 percent. Likewise, cocoa represents about 70 percent of total exports for Cote d'Ivoire while tobacco contributes only 54 percent of the total exports for Malawi. But the chosen products make the singular major contribution to total exports than any other export product in that country. Oil which contributes only about 30 percent of total exports in Egypt is still chosen as the country's major export commodity because no other product contributes up to that amount. Table 4 gives the percentage share of major export commodities for the twelve countries.

\subsection{Data Analyses and Presentation of Findings}

For the first model, the result of the test shows that for the five oil exporting countries, adverse terms of trade shocks averaged $3.62 \%$ per annum for 25 years, $2.97 \%$ per annum for 20 years, $2.15 \%$ per annum for 30 years, $1.38 \%$ per annum for 15 years and $0.83 \%$ per annum for 25 years for Gabon, Nigeria, Sudan, Egypt and Equatorial Guinea respectively. This is out of the 40 years under consideration for each country. The remaining number of years recorded favorable terms of trade shocks for the countries. Worthy of note is the peak level adverse terms of trade shocks for Gabon and Nigeria which were as high as $31.6 \%$ and $28.8 \%$ respectively for the period 1980 to 1984 and that of Sudan for the period 1985 to 1989 which was $17.9 \%$. The average adverse terms of trade shocks for the three countries within those peak periods were $6.32 \%$ per annum, $5.76 \%$ per annum and $2.15 \%$ per annum respectively. Note also that Egypt had adverse terms of trade shocks for only a period of 15 years.

For the agricultural commodity exporting countries, adverse terms of trade shocks averaged $1.15 \%$ per annum for 20 years, $1.12 \%$ per annum for 25 years, $1.87 \%$ per annum for 20 years, $1.28 \%$ per annum for 25 years and $1.52 \%$ per annum for 30 years for Cote d'Ivoire, Ghana, Kenya, Ethiopia and Malawi respectively. The remaining number of years out of the 40 years under consideration recorded favorable terms of trade shocks for the countries.

The result of the non-oil mineral resources exporting countries is very interesting because Botswana is the only country that recorded average adverse terms of trade shocks of $0.38 \%$ in only two periods of 10 years. However, Zambia recorded average adverse terms of trade shocks of $1.16 \%$ per annum over a period of 20 years out of the 40 years being considered.

From the estimate results analyzed, it is evident that all the countries except Botswana recorded adverse average terms of trade shocks higher than $0.4 \%$ per annum for the periods the shocks lasted. As documented by the World Bank, the fastest growing countries of the world lose only 0.4 percent of their GDP per annum due to terms of trade shocks (Madavo et al 2003).Therefore, the bench mark for measuring high terms of trade shocks in this study is any estimated absolute value that is greater than 0.4 percent per annum. Therefore the study confirms that adverse terms of trade shocks are high in Africa.

Estimated coefficients for changes in import intensity among the oil exporting countries mostly show unfavorable values during and after oil price collapses. Estimate result shows that unfavorable changes in import intensity averaged $2.11 \%$ per annum for 25 years, $2.46 \%$ per annum for 25 years, $2.17 \%$ per annum for 25 years, $1.38 \%$ per annum for 15 years and $2.49 \%$ per annum for 20 years for Gabon, Nigeria, Sudan, Egypt and Equatorial Guinea respectively. The remaining number of years out of the 40 years considered for each country shows favorable changes in import intensity. Even when the oil prices collapsed, import intensity in Gabon and Nigeria failed to adjust downward, cumulatively adding to unfavorable values of $12.56 \%$ and $10.80 \%$ respectively in the period 1980 to 1984 . Economic compression and non-oil export promotion also experienced only minor changes, accounting for less than $1 \%$ of GDP in each case. This means that there was no macroeconomic adjustment for both countries during this period. Therefore wrong policy choices and sometimes total lack of policy adjustments and of implementations make it impossible to adequately address the problems associated with terms of trade shocks in Africa. For the agricultural commodity exporting countries, unfavorable changes in import intensity averaged $1.5 \%$ per annum for 25 years, $1.53 \%$ per annum for 20 years, $1.67 \%$ per annum for 20 years, $1.13 \%$ per annum for 20 years and $1.43 \%$ per annum for 30 years for Cote d'Ivoire, Ghana, Kenya, Ethiopia and Malawi respectively. Botswana faired better with negligible unfavorable values of $0.71 \%$ and $0.85 \%$ in the two periods 1975 to 1979 and 1990 to 1994 respectively. This gives an average of $0.16 \%$ per annum for 10 years. 
Estimate result also indicates that unfavorable changes in economic compression were outstanding in such countries as Malawi, Sudan, Zambia and Equatorial Guinea. While Malawi had favorable outcome in only one period (1975 to 1979), Sudan achieved same in only 2 periods (1985 to 1989 and 2000 to 2004). Only Botswana again recorded favorable outcome on economic compression in all the periods. One disturbing trend is that most countries experienced either unfavorable or minor favorable economic compression during and after export slumps. This shows lack of proper management of the economy. Gabon and Nigeria recorded minor cumulative favorable changes in economic compression of only $0.80 \%$ and $0.90 \%$ respectively during the 1980 to 1984 period indicating that macroeconomic adjustment was lacking in the face of steep fall in oil prices. Sudan, Malawi, Zambia, Ghana and Kenya have also experienced unfavorable changes in economic compression during and after export slumps.

Estimate result shows that most of the countries recorded little or no export diversification during the period. Sudan and Ethiopia could record favorable changes in export promotion in only one period each (1995 to1999 for Sudan and 1990 to 1994 for Ethiopia) with negligible values of $0.35 \%$ and $0.07 \%$ respectively. Kenya and Malawi recorded favorable outcome in two periods of values $0.83 \%, 0.79 \%$ and $0.29 \%, 0.81 \%$ respectively. Nigeria and Gabon recorded their peak unfavorable changes in export promotion in the period 1970 to 1974 with absolute values amounting to $6.31 \%$ and $2.14 \%$ respectively. In the phase 1995 to 1999 , the estimate result shows a significant increase in the non-oil export promotion in Gabon, amounting cumulatively to 8.2 percent of GDP. Between 1996 and 2000, the country was undergoing significant reform and public financial retrenchment (except for the catastrophic year of 1998 when total expenditure reached close to 50 percent of GDP). The general perception among leading policymakers was that oil was in a state of permanent decline (as can be seen in table 5 in the annex) and the government needed to diversify exports and reform the public finance system. Furthermore, larger primary surpluses were needed to service the interest payments on the growing public debt. While the adjustment has not been deep enough, this phase marks a departure from Gabon's past performance. All other countries except Botswana recorded series of unfavorable values in export promotion at intervals. Even the favorable outcomes recorded by some countries are negligible in value.

The rise in adverse external debt changes for Ethiopia to 24.5\% of GDP in the 1995 to 1999 period should be noted. This was the result of the Ethiopia and Eritrea war that started in 1998 and terminated in 2000. Sudan also recorded high adverse external debt changes of $24.03 \%$ and $23.32 \%$ of GDP for the period 1995 to1999 and 2000 to 2004 respectively. Other countries such as Nigeria, Gabon, Kenya, Zambia and Malawi also recorded high adverse external debt changes with peak cumulative values of $10 \%, 24.08 \%, 18.26 \%, 10.50 \%$ and $21.91 \%$ respectively at various periods. African countries no doubt have unfavorable external debt changes. These results imply that the effects of policy adjustments to terms of trade shocks on macroeconomic performance have not adequately reduced the problems associated with such shocks in African countries.

For the second model, the result of the test shows that only three countries have Wilcoxon absolute values that are significant at varying confidence levels. The value for Botswana $\left(2.46^{* *}\right)$ is significant at $99 \%$ confidence level (**) while that of Gabon $\left(1.76^{*}\right)$ is significant at $95 \%$ confidence level $(*)$. The Wilcoxon test for Zambia $(1.74+)$ also has a value significant at $90 \%$ confidence level $(+)$. On the other hand, the values for the remaining nine countries are low and insignificant. This means that the impact of policy responses to terms of trade shocks in oil exporting countries and agricultural commodity exporting countries of Africa are markedly different.

\section{Policy Recommendations}

Based on the findings of the study, some policies that would help African countries in achieving the overall objective of reducing terms of trade shocks are highlighted:

- Long-run export diversification leading to less terms of trade volatility should be considered as a policy option aimed at private sector productivity growth. One of the reasons for the extreme terms of trade shocks among most African countries is the very concentrated nature of their exports relative to their well diversified imports. They can, however, reduce aggregate terms of trade volatility by changing the composition of exports. Researchers have already established that export diversification is facilitated by low trade barriers, avoidance of real exchange rate over-valuation and real exchange rate volatility, foreign direct investment, better education and improved institutional quality. Many countries have successfully diversified output and exports, some of them quite rapidly. Indonesia was able to reduce its oil share of exports and cut terms of trade volatility by half within a single decade. African countries should strive to make transition from primary product exports towards more knowledge based exports. Sustained high manufacturing growth rates for exports are possible. For example, between 1986 and 2000, EL Salvador, Madagascar, Nicaragua and the Philippines all achieved real growth rates of 15 percent per annum or higher for exported manufactures (Madavo et al 2003). There is no reason why 
natural resource based activities cannot become knowledge industries.

- The effects of the Dutch disease can be ameliorated by restraining government spending and by building up net foreign assets to help balance the booming inflows from oil exports. There are several ways to achieve this: build up foreign exchange assets, invest abroad, or repay external debts at faster pace. Until foreign assets reach an adequate level, all revenue windfalls must be saved while shortfalls must be met by expenditure reductions.

- New policy consensus and stronger institutions of government are advocated in order to ensure greater commitments. Stabilization funds do not work unless they are embedded in a political system that is predisposed to fiscal discipline and endowed with a system of checks and balances that facilitate transparency and accountability. Discipline is difficult to maintain in the face of a rising pool of funds. Total reform of some governmental institutions must, therefore, be undertaken.

- Finally, African countries can curtail oil price shocks by gradually exchanging some of their oil reserves for financial assets. The money earned from the sale of oil and gas reserves could be invested in a diversified financial portfolio that will generate income overtime. This would generate revenue streams for the governments that are considerably less volatile than oil revenues. Such an idea is not as radical as it may seem. The World Bank records that in 1989, the Nigerian government sold a partial share of its equity in one of its oil joint venture companies for \$2 billion. Again in 1993, it sold another portion of its equity for \$ 500million (Madavo et al 2003). There is no reason why more could not be sold, if there is enough political power supporting such a move. It should, however, be noted that countries have their peculiarities. The researcher advocates that each African country should take a critical look at its peculiar problems before selecting from the pool of policy options.

\section{Conclusion}

The study has successfully decomposed critical performance indicators of policy responses to terms of trade shocks in twelve carefully selected African countries into: changes in import intensity, economic compression, export promotion and external debt. The application of the McCathy, Neary and Zanalda (1994) method confirms that adverse terms of trade shocks are not only high in Africa but that policy indicators refuse to adjust appropriately in the face of steep fall in export prices as clearly seen in the 1980 to 1984 period for Gabon and Nigeria. The attendant implication is stunted growth and absence of economic stabilization for the countries. The few exceptions in the study, notably Botswana and to some extent, Egypt, are known among other things, to have engaged prudent economic policies in the past aimed at diversifying their export and manufacturing bases.

Secondly, the application of a Wilcoxon Matched-Pairs test reveals that the impact of policy responses to terms of trade shocks in oil exporting countries and agricultural commodity exporting countries of Africa are markedly different. The study, therefore, advocates that African countries should, henceforth, take practical steps to ameliorate the adverse effects of terms of trade shocks by carefully selecting and engaging policy thrusts that suit their particular economic problems and environments.

\section{References}

Age' nor, P-R. (2000). The Economics of Adjustment and Growth. San Diego, CA: Academic Press.

Age'nor, P-R., \& Aizenman, J. (2004). Savings and the terms of trade under borrowing constraint. Journal of International Economics, 63, 321-340. http://dx.doi.org/10.1016/S0022-1996(03)00069-2

Akpokodje, G. (2000). The effect of export earnings fluctuations on capital formation in Nigeria. AERC Research Paper 103, October.

Barro, R. J. (1996). Determinants of Economic Growth: A Cross-Country Empirical Study. NBER Working Paper 5698.

Baxter, Marianne., \& Michael Kouparitsas.(2000). What Causes Fluctuations in the Terms of Trade?. NBER Working Paper, no.7462.

Bidarkota., \& Crucini, M. J. (2000). Commodity Prices and the Terms of Trade. Review of International Economics, 8, 647-666.

Bleaney, M., \& Greenaway, D. (2001). The Impact of Terms of Trade and Real Exchange Rate Volatility on Investment and Growth in Sub-Sahara Africa. Journal of Development Economics, 65(2), 491- 500. http://dx.doi.org/10.1016/S0304-3878(01)00147-X

Broda C. (2004). Terms of trade and exchange rate regimes in developing countries. Journal of International Economics, 63, 31-58. http://dx.doi.org/10.1016/S0022-1996(03)00043-6

Broda, C., \& Tille, C. (2003). Coping with Terms-of-Trade Shocks in Developing countries. Current Issues in 
Economics and Finance, 9(11), 1-7.

Caballero R. J., \& S. Panageas. (2003). Hedging Sudden Stops and Precautionary Recessions: A Quantitative Framework. NBER Working Paper 9778.

Calvo G. A., Izquierdo, A., \& Mejia, L. (2004). On the Empirics of Sudden Stops: The Relevance of Balance-Sheet Effects. NBER Working Paper 10520.

Cashin, P., \& Pattillo, C. (2000). Terms of Trade Shocks: Are They Short-Lived or Long-Lived. IMF Working Paper, $00 / 72$.

Chami.S. (1999). External Shocks, Policy Responses and Domestic Adjustment. In Mansur, A., \& Treichel, V. (Eds.), Oman Beyond the Oil Horizon: Policies toward Sustainable Growth. International Monetary Fund Occasional Paper 185, Washington DC.

Conesa, J. C., Kehoe, T. J., \& Ruhl, K. J. (2007). Modeling great depressions: the depression in Finland in the 1990s. Federal Reserve Bank of Minneapolis Quarterly Review, 31(1), 16-44.

Daniel, James. (2001). Hedging Government Oil Price Risk. IMF Working Paper, WP/01/185.

Deaton, A. S. (1992). Understanding Consumption. Oxford: Oxford University Press. http://dx.doi.org/10.1093/0198288247.001.0001

Dennis, B. N., \& Iscan, T. B. (2005). On the terms of trade and sectoral reallocation. Review of International Economics, 13, 892-903. http://dx.doi.org/10.1111/j.1467-9396.2005.00543.x

Dennis, B. N., \& Iscan, T. B. (2006). Terms of trade risk with partial labor mobility. Journal of International Economics, 68, 92-114. http://dx.doi.org/10.1016/j.jinteco.2005.06.004

Dixit, A. K. (1989). Intersectoral Capital Reallocation under Price Uncertainty. Journal of International Economics, 26(3), 309-325. http://dx.doi.org/10.1016/0022-1996(89)90006-8

Dordunoo, C. K., \& Donkor, A. (1994). The Foreign Exchange Market and the System in Ghana. African Economic Research Consortium (AERC) Special Paper 24.

Dornbusch, R. (1983). Real Interest Rates, Home Goods, and Optimal External Borrowing. Journal of Political Economy, 91(1), 141-153. http://dx.doi.org/10.1086/261132

Ezema, B. I. (2009). Terms of Trade Shocks and Policy Responses in Africa: An Analysis of Impacts on Economic Stability and Growth. Unpublished Ph. D dissertation, Dept. of Economics, Nnamdi Azikiwe University, Awka, Anambra State, Nigeria.

Ezema, B. I., \& Amakom, U. (2011). Terms of trade shocks: a major cause of distortion in the Nigerian economy. Asian Journal of Business and Management Sciences, 1(1), 25-38.

Gavin, M. (1993). Adjusting to a Terms of Trade Shock: Nigeria, 1972-88. In Dornbusch, R. (Eds.), Policymaking in the Open Economy, Oxford University Press.

Government of Equatorial Guinea. (2006). Equatorial Oil-Government source on Economics. The Ministry of Mines, Industry and Energy.

International Monetary Fund. (2003). International Financial Statistics, 1980-2002. Washington, D.C.

Iscan, T. B., Powell, A., \& Rebucci, A. (2009). Terms-of-trade shocks and sector labor reallocation: The case of Jamaica, Guyana, and Trinidad and Tobago. Inter-American Development Bank, Washington, DC, USA.

Kaminsky, G. L. (2010). Terms of Trade Shocks and Fiscal Cycles. NBER Working Paper 15780, February.

Kehoe, T. J., \& Ruhl, K. J. (2007). Sudden stops, sectoral reallocations, and the realexchange rate. unpublished working paper, University of Texas at Austin, Texas.

Kehoe, T. J., \& Ruhl, K. J. (2008). Are Shocks to the Terms of Trade Shocks to Productivity?, Federal Reserve Bank of Minneapolis, Research Department Staff Report, no. 391.

Kose, M. A. (2002). Explaining business cycles in small open economies: How much do world prices matter? Journal of International Economics, 56, 299-327. http://dx.doi.org/10.1016/S0022-1996(01)00120-9

Madavo, C. E., Tomlinson, M. D., Mills, C. A., \& Addison, D. M. (2003). Nigeria: Policy Options for Growth and Stability. World Bank Policy Research Working Paper 26215.

McCarthy, D., Neary, J. P., \& Zanalda, G. (1994). Measuring the Effects of External Shocks and the Policy Responses to them: Empirical Methodology Applied to the Philippines. World Bank Policy Research Working 
Paper 1271.

Mendosa, E. G. (1995). The terms of trade, the real exchange rate and economic fluctuations. International Economic Review, 36, 101-137. http://dx.doi.org/10.2307/2527429

Otto, G. (2003). Terms of trade shocks and the balance of trade: there is a Harberger- Laursen-Metzler effect. Journal of International Money and Finance, 22, 155-184. http://dx.doi.org/10.1016/S0261-5606(02)00075-X

Oxford Business Group. (2007). Emerging Egypt, 2007. Oxford University Press.

Santos-Paulino, A. U. (2007). Terms of Trade Shocks and the Current Account in Small Island States. World Institute for Development Economics Research, No. 20.

Serven, L. (2002). Real Exchange Rate Uncertainty and Private Investment in LDCs. Review of Economics and Statistics.

World Bank. (1999). Global Development Finance. The World Bank, Washington, DC.

World Bank. (2000). Global Economic Prospects and the Developing Countries, 2000 Report. The World Bank, Washington, DC.

Zafar, A. (2004). What Happens when a Country does not Adjust to Terms of Trade Shocks?: The Case of Oil-rich Gabon. World Bank Policy Research Working Paper 3403, September.

Table 1. Oil Receipts and the Fiscal Situation, Nigeria, 1979 -83 (Percentage of GDP)

\begin{tabular}{|c|c|c|c|c|}
\hline Fiscal Year & Oil receipt & Spending less other receipts & \multicolumn{2}{|c|}{ Fiscal balance Millions of Naira } \\
\hline 1979 & 22.3 & 24.2 & -1.9 & -757 \\
\hline 1980 & 23.1 & 23.4 & -0.3 & -143 \\
\hline 1981 & 18.5 & 27.4 & -8.9 & $-4,734$ \\
\hline 1982 & 16.7 & 24.7 & -8.0 & $-4,524$ \\
\hline 1983 & 12.0 & 23.0 & -11.0 & $-6,650$ \\
\hline
\end{tabular}

Source: Pinto (1986)

Table 2. ADF Tests of stationarity for all variables

\begin{tabular}{|c|c|c|c|}
\hline Variable & ADF Value & Order of Integration & Significance level \\
\hline $\mathrm{Ln} \mathrm{TOT}_{\mathrm{m}}$ & -3.1047 & 1 & $5 \%$ \\
\hline $\operatorname{Ln~TOT~}_{x}$ & -3.6959 & 1 & $5 \%$ \\
\hline Ln GDPGR & -2.9730 & 1 & $1 \%$ \\
\hline $\mathrm{Ln} \mathrm{GRVT}_{\mathrm{m}}$ & -5.3304 & 1 & $1 \%$ \\
\hline Ln EL $\mathrm{E}_{\mathrm{t}}$ & -3.4018 & 1 & $5 \%$ \\
\hline Ln GRXVW & -3.6108 & 1 & $5 \%$ \\
\hline $\mathrm{Ldu}_{\mathrm{GDPT}}$ & -3.6743 & 1 & $5 \%$ \\
\hline Error Term $(\mu)$ & -6.2247 & 0 & $1 \%$ \\
\hline
\end{tabular}

Source: Author's computation

Table 3. Countries and their major Agricultural Exports

\begin{tabular}{|c|c|}
\hline Countries & Major Agricultural Exports \\
\hline Ghana & Cocoa \\
\hline Cote d'Ivoire & Cocoa \\
\hline Kenya & Tea \\
\hline Malawi & Tobacco \\
\hline Ethiopia & Coffee \\
\hline
\end{tabular}

Sources: Various Economic Surveys of the countries by Ezema (2009) 
Table 4. Percentage share of major export commodities for various countries

\begin{tabular}{|c|c|c|c|c|}
\hline S/No & Countries & $\begin{array}{c}\text { Major Export } \\
\text { Commodity (MEC) }\end{array}$ & $\begin{array}{c}\text { Percentage share of } \\
\text { MEC }\end{array}$ & $\begin{array}{c}\text { Percentage share of other } \\
\text { export commodities }\end{array}$ \\
\hline 1 & Botswana & Diamond & 60 & 40 \\
\hline 2 & Zambia & Copper & 64 & 76 \\
\hline 3 & Egypt & Oil & 30 & 60 \\
\hline 4 & Sudan & Oil & 40 & 10 \\
\hline 5 & Equatorial Guinea & Oil & 90 & 20 \\
\hline 6 & Gabon & Oil & 80 & 35 \\
\hline 7 & Ethiopia & Coffee & 65 & 40 \\
\hline 8 & Kenya & Tea & 50 & 30 \\
\hline 9 & Malawi & Tobacco & 54 & 48 \\
\hline 10 & Cote d'Ivoire & Cocoa & 70 & 10 \\
\hline 11 & Ghana & Cocoa & 52 & 96 \\
\hline 12 & Nigeria & Oil & 90 & 70 \\
\hline
\end{tabular}

Sources: Various Economic Surveys of the countries by Ezema (2009)

Table 5. Gabon's Key Economic Indicators, 1997-2005

\begin{tabular}{|c|c|c|c|c|c|c|c|c|c|}
\hline & 1997 & 1998 & 1999 & 2000 & 2001 & 2002 & 2003 & 2004 & 2005 \\
\hline \multicolumn{10}{|l|}{ Macroeconomy } \\
\hline Nominal GDP (bill CFA francs) & $3,109.1$ & $2,645.0$ & $2,840.1$ & $3,618.3$ & $3,486.5$ & $3,448.9$ & $3,520.5$ & $3,385.8$ & $3,361.4$ \\
\hline Real GDP growth (\%) & 5.7 & 3.5 & -9.6 & -1.9 & 2.0 & 0.0 & 2.8 & 1.1 & 0.8 \\
\hline Oil (\%) & -2.1 & -3.4 & -5.6 & -10.2 & -5.7 & -1.4 & 7.6 & -3.5 & -7.9 \\
\hline Non -oil (\%) & 10.2 & 7.0 & -8.9 & 2.1 & 5.3 & 0.6 & 1.0 & 3.0 & 4.0 \\
\hline Inflation (end of period) (\%) & 2.3 & 2.6 & -0.8 & 1.8 & 1.0 & 2.0 & 2.0 & 2.0 & 2.0 \\
\hline Gross investment/GDP (\%) & 31.5 & 39.1 & 23.9 & 21.8 & 25.8 & 24.4 & 22.9 & 25.8 & 26.0 \\
\hline Gross national savings/GDP (\%) & 34.5 & 20.4 & 15.3 & 28.0 & 26.0 & 25.1 & 22.9 & 19.8 & 19.9 \\
\hline \multicolumn{10}{|l|}{ Public Finance } \\
\hline $\begin{array}{l}\text { Revenue (excluding grants) GDP } \\
(\%)\end{array}$ & 33.1 & 34.5 & 28.7 & 33.6 & 30.8 & 31.5 & 30.2 & 28.3 & 27.0 \\
\hline $\begin{array}{l}\text { Total expenditure and net } \\
\text { lending/GDP }(\%)\end{array}$ & 31.5 & 48.5 & 27.5 & 22.0 & 27.6 & 28.1 & 22.8 & 24.4 & 23.7 \\
\hline Primary budget balance/GDP (\%) & 7.8 & -6.3 & 8.1 & 17.5 & 12.0 & 7.9 & 11.5 & 9.0 & 7.4 \\
\hline $\begin{array}{l}\text { Overall balance (excluding } \\
\text { grants) / GDP (\%) }\end{array}$ & 1.6 & -14.0 & 1.2 & 11.6 & 3.2 & 3.4 & 7.4 & 3.9 & 3.3 \\
\hline \multicolumn{10}{|l|}{ Debt } \\
\hline Stock of debt (\$ million) & 68.2 & 74.4 & 79.2 & 71.2 & 73.7 & 70.3 & 67.4 & 67.0 & $\ldots \ldots$ \\
\hline $\begin{array}{l}\text { Debt }- \text { service ratio }(\% \text { of } \\
\text { revenue) }\end{array}$ & 11.8 & 14.6 & 13.5 & 20.1 & 41.0 & 13.3 & $\ldots$ & $\ldots$. & $\cdots \cdots$ \\
\hline $\begin{array}{l}\text { Exchange rate (CFA francs per } \\
\text { U.S. dollar) }\end{array}$ & 583.7 & 590.0 & 614.9 & 710.0 & 732.5 & 695.4 & 80.1 & $\ldots$. & $\ldots$. \\
\hline
\end{tabular}

Source: Government of Gabon, IMF, and Bank Staff estimates 